is a still further improvement in point of efficacy and palatableness.

As to the other part of "G. E. D." 's note, in which he proceeds dogmatically to assert (ex cathedr, as it were) that the remedy is not of much value, I must observe that he is simply speaking with rashness ufon a subject with which he is obviously unacquainted; as he will see, when you may do me the honour of publishing the additional cases. But, besides this, as a stomachic, or digestive, to be used in the vast majority of cases of dyspepsia, - on which theoretic principle alone I originally used it, and not, let me repeat, as a specific cure for diabetes (though that was the result), - I am prepared to assert on the basis of a very large experience, that it is, and will sooner or later be universally acknowledged to be, superior to every other remedy hitherto employed, and as wonderful for its power as for its simplicity.

I have not, either before or now, put forth claims to the discovery of any new and previously-unimagined principle in this matter; I have only, as a practical physician, applied, for the alleviation of suffering, that natural agency, of the powers of which Dr. Spallanzani, nearly a century ago, gave clear indications; though then, only as a demonstration of chemical and physiological fact, and not with the view of establishing any distinct therapeutical doctrine, such as I have here advanced, and am prepared to prove, I hope, to the satisfaction of the profession.

$$
\begin{gathered}
\text { Colmore-row, Birmingham, } \\
\text { April, 1856. }
\end{gathered}
$$

** We regret that we have hitherto been unable to give insertion to the article mentioned by Dr. Nelson. It shall be published at the earliest opportunity.-ED. L.

\section{REMUNERATION OF POOR-LAW SURGEONS.} To the Editor of The LaNCET.

SrR,-As there is an important movement just now going on amongst the Poor-law Medical Ofiicers, and as it has been proposed in certain high quarters to remunerate their services at so much per case, I beg to forward to you an example of the pernicious effects of such a system. The following report is taken from the Cambridge Independent Press of Siturday, the 15 th inst. The remuneration at per case, in my opinion, will never act harmoniousiy between the guardians, poor, and medical officer, for it will be the constant endeavour of the former, as in the present case, to give as few orders as possible; and at the present rate of wages in the County District, it is utterly out of the power of the poor adequately to remunerate the medical officer for his services, and even if they could, such is the moral principle, that nine cases out of ten they would not if they could pay, unless compelled by the county court; and ultimately, directly or indirectly, the medical officer would be forced to attend those cases for nothing, or be stigmatised as a cruel, hard-hearted man, and as such, shunned by all the gentry of the neighbourhood. Why medical men should be called upon to render services to the public, which ought to be borme by the whole of the ratepayers, I never conld understand; no other class of the community are called upon upon to do so, and the sooner a dead stand is made against it the better. I know full well that our profession is considered to be a profession of humanity, and because we do cheerfully, and withont any consideration ervices that neither the church nor the law would do without being amply rewarded, which frequently lead to a premature grave, the public thinks that it has a right to impose what ever terms it chooses upon us. Now, in my opinion, with a donble income tax, high price of corn, drugs, \&c., and, I trust, a willing House of Commons, is the time to undeceive it, and if the profession is only true to itself, victory is our own.

A POOR-IAW OFFICER OF FOURTEEN YEARS' STANDING.

"MeLdreth. - An inquest was held at Meldreth, on Saturday last, before F. Barlow, Esq., coroner for the county, on view of the body of Stephen Giffin, aged six years. From the evidence, it appeared that the father was in work at 11s. a week, out of which he had to maintain himself, his wife, and four children. The whole four children had had the measles, and an order from the Royston Union had been obtained for the attendance of the medical officer upon one child only (the baby). The deceased, who was from his birth a sickly child, had had no attendance whatever until the day of his death, when the assistant to the medical officer being at the house in attendance on the baby, was requested by the mother to see the deceased, which he most properly did without an order, and directed that medicine should be supplied, but required that an order should be obtained from the relieving officer. The mother obtained the order that afternoon, and went to the medical officer's surgery for the medicine, which was instantly supplied; but on her return, the child would take but little of it, and died within about two hours after.The mother stated that the child had nothing to eat but bread, and bread and butter, and Mr. Metcalf, surgeon, of Meldreth, being examined at the inquest, stated his opinion of the cause of death to be exhaustion after measles, accelerated by want of proper nourishment. In the Royston Union the per case system for medical relief exists, and the mother stated that she could get an order for medical attendance upon only one child, though all four were suffering from the measles. Though there was too much reason to believe that there was not only bad management in the family, but that much of the husband's earnings was spent at the ale-house, still, with 11s. a week only to maintain a man, his wife, and four children, all that time requiring proper nourishing diet, it would be preposterous to suppose that it could have been supplied out of the earnings, and that the parent could pay for independent medical attendance upon all but one child."-Verdict, "Natural causes."

\section{To the Editor of THE LANCET}

Sir,-In the number of THE LANCET for March 15th, you inserted a letter of mine regarding the duties and remuneration of the medical officer of the Maryport district of the Cockermouth Union. In confirmation of the assertions contained in that letter, I beg to forward yon a statement of my duties, and the remuneration I received for the last quarter. During that time I attended 90 cases of disease, many of them cases of fever; I made 651 visits; and travelled 189 miles into the country: 26 of the above cases being at a distance from the town, some as far as seven miles from my residence. For these services I received the sum of $£ 710 \mathrm{~s}$, with $10 \mathrm{~s}$. for attendance upon a midwifery case, which is at the rate of $1 s .8 d$. per ease, and $2 \frac{3}{4} d$. per visit. If I deduct travelling expences from the above, at the rate of $7 d$. per mile, which I find it would cost for horse hire, I shall then have $2119 s .9 d$. remaining, with which I must pay for medicine, instruments, \&c., for ninety patients. After I have done this, I should like the Poor-law Board to inform me what remuneration I have received for my services for the past quarter. Yet, in spite of statements such as these, they tell me in their letter that they have "read and duly considered the representations" I have submitted to them, but they "are not prepared to direct that my salary should be increased;" at the same time they state, that if the guardians should think that I am not adequentely remuncrated, "the Board will give their further consideration to this subject." Comparing the above statement with the letter of the Poorlaw Board, there are only three conclusions to which I can arrive:- that they do not believe my statement; that they have not the power (which the General Consolidated Order says they have) of increasing the salary without the consent of the gnardians; or that they do not care whether the medical offeer receives any remuneration, so long as the duties are performed and they are not troubled on the subject.

We are often told that, if dissatisfied, we can resign; that plenty are ready to take office upon the same terms. I am not at all surprised at this; there are many holding Poor-law appointments who have not the Apothecaries' certificate, and who yet have signed contracts to supply medicine and attendance for a sum of money, thereby rendering themselves liable to a penalty of $£ 20$; for I am not aware that even the Poorlaw Board have any power to dispense with the Apothecaries licence in those who take such contracts. The competition, then, to which the legally-qualified are subjected, is not a fair one.

Maryport, April, 1856.

I remain, Sir, your obedient servant, Joseph Pearson.

\section{HOSPITAL FOR THE CURE OF THE INSANE POOR}

To the Editor of THE LAvaET.

SIR, - Should you consider the following remarks of sufficient importance, and not altogether foreign to the aim and objects of a journal such as THE LANCET, I would venture to ask you to allow them space in an early number.

You will perceive in the columns of The Times for March 28th, that the Middlesex magistrates contemplate enlarging 